\title{
Heterologous Expression and Purification of SARS-CoV2 Nucleocapsid Protein
}

Ankur Garg ${ }^{1,2}$, Lihong Liu³, David D. Ho ${ }^{3}$ and Leemor Joshua-Tor ${ }^{1,2, *}$

${ }^{1}$ W. M. Keck Structural Biology Laboratory, Cold Spring Harbor, New York, 11724 USA; ${ }^{2}$ Howard Hughes Medical Institute, Cold Spring Harbor laboratory, One Bungtown Road, Cold Spring Harbor, New York, 11724 USA; ${ }^{3}$ Aaron Diamond AIDS Research Center, Wu Family China Center, Columbia University Vagelos College of Physicians and Surgeons, 701 W $168^{\text {th }}$ St, New York, NY 10032, USA

*For correspondence: leemor@cshl.edu

[Abstract] This protocol describes a step by step method for heterologous expression of SARS-CoV2 Nucleocapsid $(\mathrm{N})$ protein in Escherichia coli. Moreover, this protocol includes steps to purify the $\mathrm{N}$ protein to high purity and homogeneity. Thus, purified protein can be used for ligand binding assays and other biochemical experiments.

Keywords: COVID-19, SARS CoV2, Nucleocapsid protein, Recombinant expression, Protein purification

[Background] Since its detection in late 2019 in Wuhan, China, SARS-CoV2 infections have been rampant around the world (Wu et al., 2020). In an effort to follow the course of early infections, the nucleocapsid protein $(\mathrm{N})$ was used along with the spike protein $(\mathrm{S})$ in serological assays to monitor the course of early infections in the New York area. $\mathrm{N}$ is one of the most highly expressed viral protein, and therefore a good target to follow. To facilitate these assays, a purification protocol was developed for $\mathrm{N}$ and used successfully in these studies.

\section{Materials and Reagents}

1. Syringe (VWR International, catalog number: BD309653)

2. $\quad 0.2 \mu \mathrm{m}$ Syringe filters (VWR International, catalog number: 28196-368)

3. Econo-Column $2.5 \times 10 \mathrm{~cm}$ (Bio-Rad, catalog number: 737-4251)

4. HiTrap Heparin HP column 5 ml (GE Healthcare, catalog number: 17040703)

5. Amicon Ultra-15 Centrifugal Filter Units 30 kD MWCO (Millipore, catalog number: UFC803096)

6. HiLoad $16 / 600$ Superdex200 pg column (GE Healthcare, catalog number: 17106901)

7. 96-well Uniplate (Fisher Scientific, catalog number: 09-003-36)

8. Culture plates (Thermo Fisher Scientific, catalog number: 0 8-757-100D)

9. Culture flasks (Thermo Fisher Scientific, catalog number: 09-552-70)

10. E. coli Rosetta 2 (DE3) chemically competent cells (Novagen, catalog number: 71400-3)

11. pET28a(+)_Nucleocapsid plasmid [pET28a(+) vector (Novagen, catalog number: 69864-3) with SARS CoV2 Nucleocapsid encoding gene fused to an in frame C-terminal AAALE linker and a 6xHis tag] 
Note: $p E T 28 a(+) \_n u c l e o c a p s i d$ plasmid is available upon request from the corresponding author.

12. Agar (Fisher Scientific, catalog number: BP1423-500)

13. Yeast extract (Fisher Scientific, catalog number: BP1422-2)

14. Tryptone (Fisher Scientific, catalog number: BP1421-2)

15. Di-potassium hydrogen phosphate $\left(\mathrm{K}_{2} \mathrm{HPO}_{4}\right)$ (Sigma-Aldrich, catalog number: 60353)

16. Potassium dihydrogen phosphate $\left(\mathrm{KH}_{2} \mathrm{PO}_{4}\right)$ (Sigma-Aldrich, catalog number: 92214$)$

17. Sodium hydroxide $(\mathrm{NaOH})$ (Sigma-Aldrich, catalog number: S8045)

18. 1,000x Kanamycin stock solution $(50 \mathrm{mg} / \mathrm{ml}$ ) (Gold Biotechnology, catalog number: K-120-25)

19. $1,000 \times$ Chloramphenicol stock solution (34 mg/ml) (Gold Biotechnology, catalog number: C-1055)

20. 1 M IPTG (IsoPropyl-1-Thio-B-D-Galactopyranoside) (Gold Biotechnology, catalog number: I2481C50)

21. Tris (Gold Biotechnology, catalog number: T-095-1)

22. Sodium Chloride ( $\mathrm{NaCl}$ ) (Sigma-Aldrich, catalog number: $\mathrm{S} 7653)$

23. $\beta$-Mercaptoethanol ( $\beta$-Me) (Sigma-Aldrich, catalog number: M6250-250ML)

24. $100 \%$ Glycerol (Fisher Scientific, catalog number: G33-4)

25. TurboNuclease (Accelagen, catalog number: N0103M)

26. Protease inhibitor cocktail $(2 \mu \mathrm{M}$ Pepstatin, $6 \mu \mathrm{M}$ Leupeptin, $1 \mu \mathrm{M}$ PMSF, and $2 \mathrm{mM}$ Benzamidine) (Sigma-Aldrich, catalog numbers: 11524488001, 11017128001, p7626-25, B6506-25)

27. Polyethylenimine (PEI) (Acros Organics, catalog number: AC178571000)

28. Ni-NTA Agarose resin (Qiagen, catalog number: 30250)

29. Bradford assay dye reagent concentrate (Bio-Rad, catalog number: 500-0006)

30. Imidazole (Affymetrix, catalog number: 17525)

31. ATP (P212121, catalog number: Cl-00015-25G)

32. $12 \%$ Mini-PROTEAN TGX Precast protein gel, 15-well (Bio-Rad, catalog number: 4561046)

33. 4x Laemmli protein sample buffer for SDS-PAGE (Bio-Rad, catalog number: 1610747)

34. InstantBlue Ultrafast protein gel stain (VWR Scientific, catalog number: 95045-070)

35. Liquid Nitrogen

36. Luria-Bertani (LB) medium (see Recipes)

37. Terrific Broth (TB) medium (see Recipes)

38. Resuspension buffer (see Recipes)

39. Ni-NTA buffers

Wash buffer (see Recipes)

Elution buffer 1 (see Recipes)

Elution buffer 2 (see Recipes)

40. Heparin buffers

Heparin buffer A (see Recipes) 
Heparin buffer B (see Recipes)

Heparin dilution buffer (see Recipes)

41. Size exclusion (SEC) buffer (see Recipes)

42. 10x SDS-PAGE running buffer (see Recipes)

\section{Equipment}

1. Nalgene PPCO Centrifuge bottles (1 L) (Fisher Scientific, catalog number: 05-562-25)

2. Ultracentrifuge tubes (Polycarbonate bottle, $38 \times 102 \mathrm{~mm}, 70 \mathrm{ml}$ ) (Beckman Coulter Life Sciences, catalog number: 355655)

3. Beaker (Sigma-Aldrich)

4. Magnetic stirrer (Sigma-Aldrich)

5. Rocker (IBI Scientific)

6. Sonicator (12.7 $\mathrm{mm}$ tip) (QSonica LLC)

7. Incubator (at $37^{\circ} \mathrm{C}$ )

8. Incubator shaker (Eppendorf New Brunswick Innova)

9. Centrifuge (Beckman Coulter Life Sciences, model: J6-MI)

10. Rotor (Beckman Coulter Life Sciences, model: JS 4.3)

11. Ultracentrifuge (Beckman Coulter Life Sciences)

12. Ultracentrifuge Rotor (Beckman Coulter Life Sciences, model: Ti45)

13. Mini-PROTEAN ${ }^{\circledR}$ Tetra Vertical Electrophoresis Cell system (Bio-Rad, catalog number: 1658005)

14. AKTA pure FPLC system (GE Healthcare)

15. Cold room

16. UV-VIS spectrophotometer (Thermo Fisher Scientific, model: NanoDrop1000)

\section{Procedure}

1. SARS CoV2 $\mathrm{N}$-protein was cloned into pET28a(+) with an in-frame AAALE linker and 6xHis tag at C-terminal.

2. Transform $50 \mu \mathrm{l}$ of chemically competent E. coli Rosetta 2 (DE3) cells with the 50-100 $\mathrm{ng}$ pET28a(+)_Nucleocapsid plasmid according to manufactures instructions. Plate the revival mix onto LB agar plate with Kanamycin (Kan) $(50 \mu \mathrm{g} / \mathrm{ml})$ and Chloramphenicol (Cam) $(34 \mu \mathrm{g} / \mathrm{ml})$ antibiotics, and leave it for incubation overnight in $37^{\circ} \mathrm{C}$ incubator.

3. Select a single colony from the LB agar plate and inoculate into $100 \mathrm{ml}$ LB media (supplemented with Kan $[50 \mu \mathrm{g} / \mathrm{ml}]$ and Cam [34 $\mu \mathrm{g} / \mathrm{ml}])$ at $37{ }^{\circ} \mathrm{C}$ at $220 \mathrm{rpm}$ shaking.

4. Inoculate $5-10$ L TB media (supplemented with $50 \mu \mathrm{g} / \mathrm{ml} \mathrm{Kan}$ and $34 \mu \mathrm{g} / \mathrm{ml} \mathrm{Cam}$ ) with $1 \%$ overnight culture and shake at $200 \mathrm{rpm}$ at $37^{\circ} \mathrm{C}$ till the cells grow to an OD of 1.5. 
5. Induce protein expression by adding IPTG to final concentration of $0.5 \mathrm{mM}$, and reduce the culture temperature to $18^{\circ} \mathrm{C}$. Let the culture shake at $180 \mathrm{rpm}$ for next $16-18 \mathrm{~h}$.

6. Harvest the cells by centrifuging culture at $4,000 \times g$ for $20 \mathrm{~min}$ at $4{ }^{\circ} \mathrm{C}$, followed by resuspending the pellet in $20 \mathrm{ml}$ resuspension buffer per liter culture. Pellet can be stored frozen in $-80^{\circ} \mathrm{C}$ for long term storage. Further purification steps were performed with samples either on ice or in cold room. Where otherwise, temperature is mentioned.

7. Thaw out the pellet in water bath (at $30^{\circ} \mathrm{C}$ ) and add $2 \mathrm{U} / \mathrm{ml}$ TurboNuclease in the lysate, and lyse the cells by sonication at $100 \%$ amplitude for $4-5 \mathrm{~min}$ ( $3 \mathrm{~s}$ pulse on and $6 \mathrm{~s}$ pulse off). For large volumes (>150 ml), divide the lysate into two beakers and sonicate separately.

8. Add PEl (final $0.2 \%$ ) to the lysate while mixing with a magnetic stirrer for 5 min and ultracentrifuge the lysate for $1 \mathrm{~h}$ at 95,000 $\mathrm{xg}$.

9. Filter the cleared lysate through a $0.2 \mu \mathrm{m}$ syringe filter. Equilibrate the Ni-NTA agarose beads ( $0.5 \mathrm{ml}$ beads per liter culture) in Wash buffer and add it to the cleared lysate. Let the Ni-NTA beads incubate on a rocker for $1 \mathrm{~h}$ in cold room. [Total volume of Ni-NTA beads $=1$ column volume $(\mathrm{CV})]$

10. Separate the Ni-NTA beads from the lysate under gravity flow using Econo-column.

11. Wash the beads with 20 column volumes (CV) of Wash buffer and then elute the protein in Elution buffer 1 ( 4 fractions of $1 \mathrm{CV}$ each). Most of the protein elutes out from the Ni-NTA beads with maximum protein in fraction 3 (Figure 1).

12. Elute the remaining protein with Elution buffer 2 (2 fractions of $2 \mathrm{CV}$ each).

13. Measure the protein amount with Bradford method according to manufacturer's instructions.

14. Dilute the $10 \mathrm{ul}$ of collected fractions with the $4 \mathrm{x}$ Laemmli protein sample buffer, heat for $5 \mathrm{~min}$ at $95^{\circ} \mathrm{C}$ and resolve the samples on SDS-PAGE at $200 \mathrm{~V}$ to analyze the purity of protein (Figure 1).

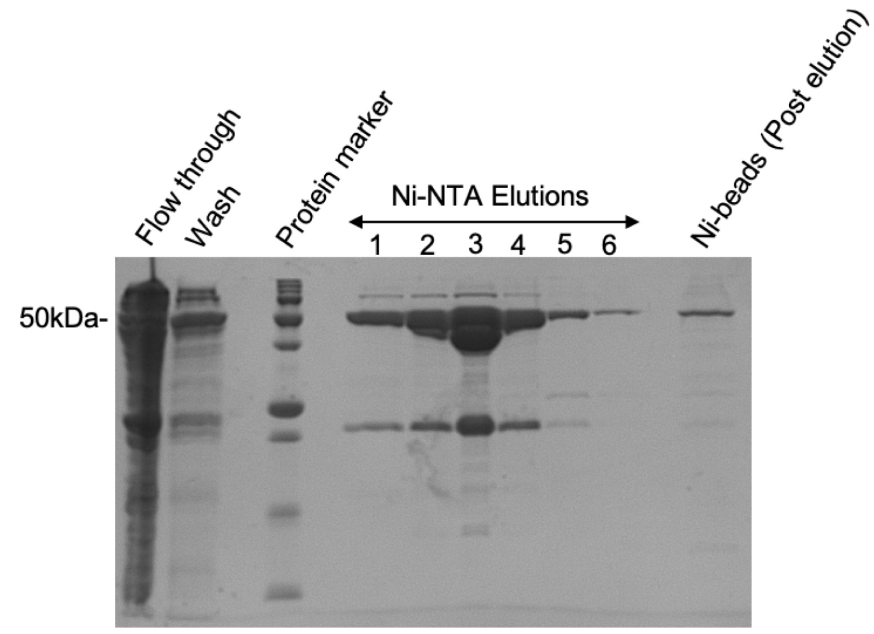

Figure 1. A representative SDS-PAGE for Ni-NTA affinity chromatography for SARS CoV2

N-protein. Different samples collected during Ni-NTA were analyzed on 12\% SDS-PAGE. Elution fractions are numbered on top of the gel. Fractions 1-4 and 5-6 show protein eluted with 
Elution buffers 1 and 2 respectively. Some protein stays bound to Ni-beads after elution with $500 \mathrm{mM}$ imidazole buffer.

15. Pool the elution fractions and dilute 1:1 using Heparin dilution buffer to reduce the $\mathrm{NaCl}$ concentration to $100 \mathrm{mM}$.

16. Connect HiTrap Heparin-HP column to AKTA pure system and equilibrate the column with $5 \mathrm{CV}$ Heparin buffer A before loading the diluted protein on column using the sample pump. A constant flow rate of $4 \mathrm{ml} / \mathrm{min}$ was used for Heparin chromatography.

17. Wash the Heparin HP column with $8 \mathrm{CV}$ Heparin buffer A, followed by protein elution using a linear gradient from 10 to $100 \%$ Heparin buffer B over 150 ml. Protein will elute between $60-70 \%$ Heparin buffer B concentration.

18. Collect $1-2 \mathrm{ml}$ fractions in clean tubes and run the peak fractions on SDS-PAGE for analyzing the purity of the protein. A typical Heparin-HP elution chromatogram for $\mathrm{N}$-protein is shown in Figure 2.

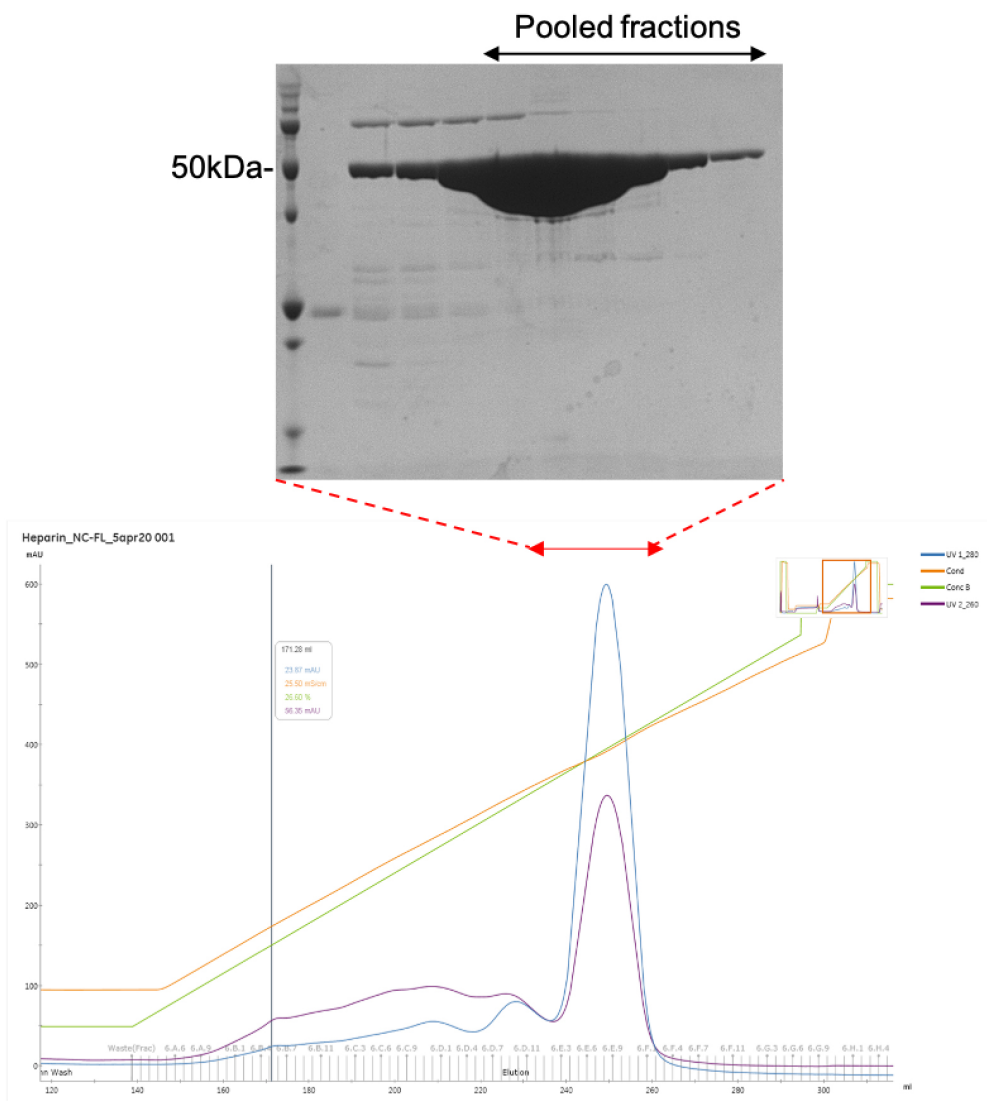

Figure 2. A representative SDS-PAGE and chromatogram for Heparin HP $(5 \mathrm{ml})$ chromatography for SARS CoV2 N-protein. N-proteins eluted out between 60-70\% Heparin buffer $B$ and the fractions covering whole peak (marked with red arrow on top of the peak) were analyzed on $12 \%$ SDS-PAGE. Fractions having pure protein were further purified on size exclusion chromatography. 
19. Pool the pure fractions from HiTrap Heparin HP elutions and concentrate it to $\sim 2 \mathrm{ml}$ final volume using 30 kD MWCO Amicon Ultra-15 Centrifugal Filter Units as per manufacturer's instructions.

20. Equilibrate the HiLoad 16/600 Superdex200 pg column with SEC buffer and inject the concentrated protein using capillary loop followed by eluting it out with SEC buffer at $1 \mathrm{ml} / \mathrm{min}$ flow rate. A single peak for the homogenous protein will be observed.

21. Collect $1 \mathrm{ml}$ fractions in clean tubes and run the peak fractions on SDS-PAGE for analyzing the protein purity (Figure 3 ).

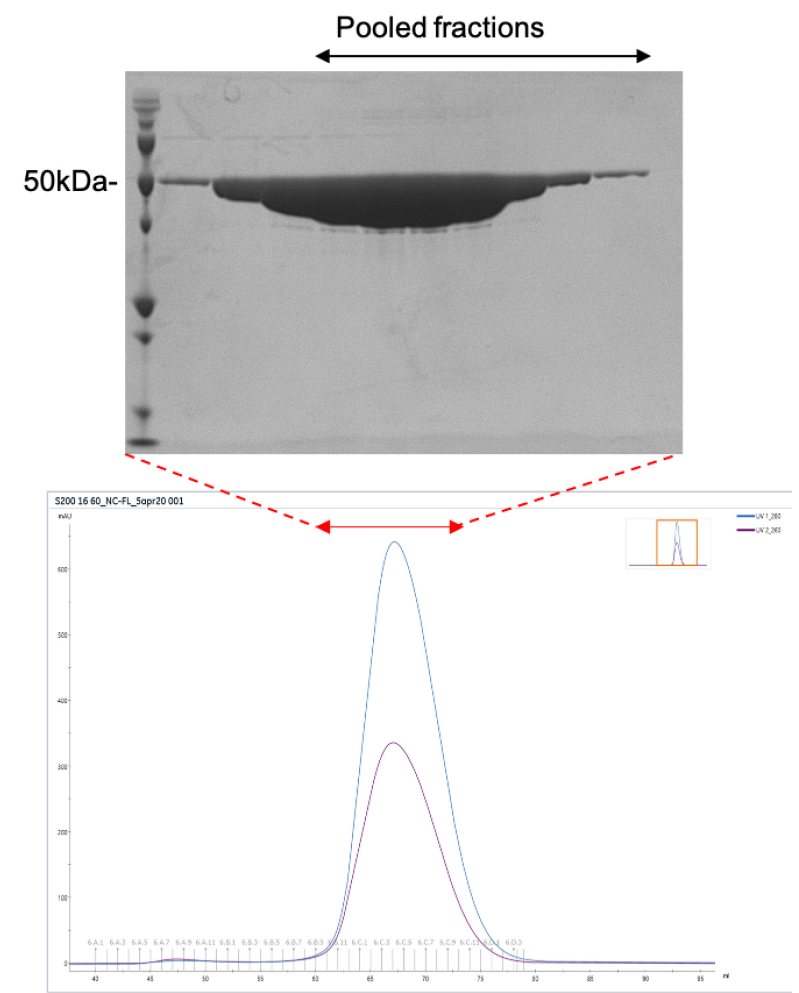

Figure 3. A representative SDS-PAGE and chromatogram for the size exclusion chromatography for SARS CoV2 N-protein. Concentrated protein was loaded on HiLoad 16/600 Superdex200 pg column and fractions covering whole peak (marked with red arrow in chromatogram) were analyzed on a $12 \%$ SDS-PAGE. Only pure protein containing fractions (marked on top of the gel) were pooled, concentrated and stored.

22. Pool the pure protein containing fractions and concentrate using 30 kD MWCO Amicon Ultra15 Centrifugal Filter Units to desired concentration.

23. Protein aliquot can be flash frozen in liquid nitrogen and stored at $-80^{\circ} \mathrm{C}$ for long term storage.

\section{Data analysis}

1. This section explains how to determine the yield and purity of protein after size exclusion chromatography. 
a. A Spectrophotometer/NanoDrop can be used to measure the absorbance at $280 \mathrm{~nm}$ and $260 \mathrm{~nm}$.

b. The $280 \mathrm{~nm}$ absorbance and the correction factor of 0.932 was used to determine the real concentration of $\mathrm{N}$ protein (Real cons $=\mathrm{A}_{280} / 0.932$ ). Purified protein shows a 260/280 ratio between $0.55-0.60$, which represents that there is no nucleic acid contamination in the protein.

2. The UNICORN 7.4 software (GE Healthcare) was used to visualize the chromatograms and preparing chromatogram figures.

\section{$\underline{\text { Recipes }}$}

1. LB medium
a. Weigh out $10 \mathrm{~g}$ tryptone, $5 \mathrm{~g}$ yeast extract, and $10 \mathrm{~g} \mathrm{NaCl}$
b. Add up to $900 \mathrm{ml}$ deionized water
c. Adjust $\mathrm{pH}$ to 7.5 with $5 \mathrm{~N} \mathrm{NaOH}$
d. Adjust the final volume to $1 \mathrm{~L}$ with deionized water
e. Sterilize by autoclaving at $121^{\circ} \mathrm{C}$ for $30 \mathrm{~min}$
f. Store at room temperature

2. TB medium
a. Add $900 \mathrm{ml}$ water to $20 \mathrm{~g}$ tryptone, $24 \mathrm{~g}$ yeast extract and $4 \mathrm{ml}$ glycerol
b. Stir until the solutes have dissolved and sterilize by autoclaving
c. Prepare $100 \mathrm{ml}$ Phosphate buffer $\left(0.17 \mathrm{M} \mathrm{KH}_{2} \mathrm{PO}_{4}+0.72 \mathrm{M} \mathrm{K}_{2} \mathrm{HPO}_{4}\right)$ and sterilize by autoclaving
d. When at room temperature mix both the solutions and use immediately

3. Resuspension buffer

$\begin{array}{ll}\text { Tris } & 25 \mathrm{mM}(\mathrm{pH} 8.0) \\ \mathrm{NaCl} & 500 \mathrm{mM} \\ \beta-\mathrm{Me} & 2 \mathrm{mM} \\ \text { Glycerol } & 5 \% \\ \text { Imidazole } & 10 \mathrm{mM} \\ \text { Protease inhibitor cocktail }\end{array}$

4. Ni-NTA buffers

a. Wash buffer

$\begin{array}{ll}\text { Tris } & 25 \mathrm{mM}(\mathrm{pH} \mathrm{7.4)} \\ \mathrm{NaCl} & 500 \mathrm{mM} \\ \beta-\mathrm{Me} & 2 \mathrm{mM} \\ \text { Glycerol } & 5 \% \\ \text { Imidazole } & 50 \mathrm{mM} \\ \text { ATP } & 1 \mathrm{mM}\end{array}$


b. Elution buffer 1

$\begin{array}{ll}\text { Tris } & 25 \mathrm{mM}(\mathrm{pH} 7.4) \\ \mathrm{NaCl} & 200 \mathrm{mM} \\ \beta-\mathrm{Me} & 2 \mathrm{mM} \\ \text { Glycerol } & 5 \% \\ \text { Imidazole } & 250 \mathrm{mM} \\ \text { Elution buffer } 2 & \\ \text { Tris } & 25 \mathrm{mM}(\mathrm{pH} \mathrm{7.4)} \\ \mathrm{NaCl} & 200 \mathrm{mM} \\ \beta \text {-Me } & 2 \mathrm{mM} \\ \text { Glycerol } & 5 \% \\ \text { Imidazole } & 500 \mathrm{mM}\end{array}$

5. Heparin buffers
a. Heparin buffer $\mathrm{A}$
Tris
$25 \mathrm{mM}(\mathrm{pH} 7.4)$
$\mathrm{NaCl}$
$100 \mathrm{mM}$
$\beta-\mathrm{Me}$
$2 \mathrm{mM}$

b. Heparin buffer $B$

$\begin{array}{ll}\text { Tris } & 25 \mathrm{mM}(\mathrm{pH} 7.4) \\ \mathrm{NaCl} & 1 \mathrm{M} \\ \beta-\mathrm{Me} & 2 \mathrm{mM} \\ \text { Heparin dilution } & \text { buffer } \\ \text { Tris } & 25 \mathrm{mM}(\mathrm{pH} 7.4) \\ \beta-\mathrm{Me} & 2 \mathrm{mM}\end{array}$

6. Size exclusion (SEC) buffer

$\begin{array}{ll}\text { Tris } & 25 \mathrm{mM}(\mathrm{pH} 8.0) \\ \mathrm{NaCl} & 500 \mathrm{mM} \\ \beta-\mathrm{Me} & 2 \mathrm{mM}\end{array}$

7. 10x SDS-PAGE running buffer
a. Dissolve $30 \mathrm{~g}$ Tris base, $144 \mathrm{~g}$ glycine and $10 \mathrm{~g}$ SDS in $1000 \mathrm{ml}$ of deionized water
b. $\mathrm{pH}$ of solution should be 8.3 and no $\mathrm{pH}$ adjustment is required
c. Store the buffer at room temperature and dilute to $1 \mathrm{x}$ with deionized water before use

\section{Acknowledgments}

This work was supported by the Meier \& Linnartz Family Foundation. L.J. is an Investigator of the Howard Hughes Medical Institute.

Competing interests: Authors declare no competing interest. 


\section{$\underline{\text { References }}$}

1. Wu, F., Zhao, S., Yu, B., Chen, Y. M., Wang, W., Song, Z. G., Hu, Y., Tao, Z. W., Tian, J. H., Pei, Y. Y., Yuan, M. L., Zhang, Y. L., Dai, F. H., Liu, Y., Wang, Q. M., Zheng, J. J., Xu, L., Holmes, E. C. and Zhang, Y. Z. (2020). A new coronavirus associated with human respiratory disease in China. Nature 579(7798): 265-269. 